\title{
A PILOT STUDY OF METHODS FOR MEASURING THE RESIDUAL PROPERTIES OF CONCRETE EXPOSED TO ELEVATED TEMPERATURES
}

\author{
PILOTNA ŠTUDIJA MERJENJA ZAOSTALIH LASTNOSTI BETONA \\ IZPOSTAVLJENEGA POVIŠANIM TEMPERATURAM
}

\author{
Iva Rozsypalová, Petr Daněk, Hana Šimonová, Zbyněk Keršner, Dalibor Kocáb \\ Brno University of Technology, Faculty of Civil Engineering, Veveří 331/95, 60200 Brno, Czech Republic \\ iva.rozsypalova@vutbr.cz
}

Prejem rokopisa - received: 2017-01-09; sprejem za objavo - accepted for publication: 2017-12-21

doi: $10.17222 / \mathrm{mit} .2017 .004$

\begin{abstract}
This pilot study and literature review was performed with the purpose of preparing for subsequent extensive research focused on the design of effective diagnostic methods for determining the current state of concrete structures damaged by high temperatures during exposure to fire. During the pilot study, specimens were prepared from ordinary concrete with dense aggregate, and were subsequently loaded by temperatures of $(200,400,600,800,1000$ and 1200$){ }^{\circ} \mathrm{C}$. In addition, one set of the specimens was kept as reference specimens without thermal loading. After the thermal loading of the six sets of specimens had cooled, selected non-destructive tests were performed; i.e., the Silver Schmidt hammer rebound test, the ultrasonic pulse velocity test, and the impact-echo method. Furthermore, the compressive strength of the specimens was determined destructively to provide reference data. The experiments indicated the fact that the commonly used non-destructive methods are not suitable for estimating the compressive strength of concrete exposed to temperatures higher than $600{ }^{\circ} \mathrm{C}$. This indicates that it is necessary to derive new calibration relationships for such conditions. It was also found that an apparent increase occurred in the hardness and modulus of elasticity for the tested concrete when it was exposed to temperatures greater than $1000{ }^{\circ} \mathrm{C}$.

Keywords: concrete, high temperature, Schmidt rebound, ultrasonic pulse velocity
\end{abstract}

S pomočjo te pilotne študije in literaturnega pregleda so se avtorji pripravili na nadaljnjo intenzivno raziskavo oblikovanja učinkovite metode določevanja stanja poškodovanih betonskih konstrukcij po požarih zaradi njihove izpostavljenosti visokim temperaturam. Med pilotno študijo so pripravili vzorce iz običajnega betona z gostimi agregati in jih nato izpostavili visokim temperaturam $(200,400,600,800,1000$ and 1200$){ }^{\circ} \mathrm{C}$. Eno garnituro vzorcev, ki ni bila izpostavljena visokim termičnim obremenitvam so obdržali kot referenčni material. Po termični obremenitvi šestih garnitur vzorcev so jih ohladili in izvedli izbrane metode neporušnih preiskav in sicer: Silver-Schmidtov odbojni test s kladivom, test ultrazvočne pulzne hitrosti in udarno-odmevno metodo. Nadalje so določili še tlačno trdnost vzorcev s standardno porušno metodo. Preiskave so nakazale, da neporušne preiskave ne dajejo ustreznih vrednosti za oceno tlačne trdnosti betona, ki je izpostavljen temperaturam nad $600{ }^{\circ} \mathrm{C}$. To pomeni, da je potrebno izdelati nove kalibracijske algoritme za takšne pogoje. Avtorji raziskave so ugotovili, da pride celo do navideznega povišanja trdote in elastičnega modula pri betonu, ki je bil izpostavljen temperaturam višjim od $1000{ }^{\circ} \mathrm{C}$.

Ključne besede: beton, povišane temperature, Schmidtov odboj, hitrost ultrazvočnih pulzov

\section{INTRODUCTION}

High temperatures acting upon concrete trigger a number of physical and chemical processes that result in transformations in the composite's structure and undesirable changes in its physico-mechanical properties, in general. ${ }^{1}$ A lot of research teams have been investigating the changes caused by elevated temperatures. Given the variety of concrete types, parameters and behaviours that exist under normal conditions, different behaviours during and after thermal loading can be expected. ${ }^{1,2}$ Concrete made with quartz aggregate is thermally more stable than concrete containing carbonate aggregate. ${ }^{3}$ The degradation of compressive strength due to high temperatures is a property that seems to be receiving much attention. ${ }^{1,4}$ The determination of compressive strength by non-destructive methods has proved that different water-to-cement $(w / c)$ ratios have no significant influence on the dependence of the ultrasonic pulse velocity on the strength at a temperature of $400-600{ }^{\circ} \mathrm{C} .{ }^{5}$ The compressive strength and modulus of elasticity of ultra-high-strength concrete (UHSC) is generally reduced by high temperatures to a lesser degree than is the case with normal and high-strength concretes. ${ }^{6}$ The influence of the addition of various types of fibres is also often studied. A frequently tested example involves the addition of polypropylene (PP) fibres to the cement matrix, with the aim of compensating for the higher pore pressure that occurs in concrete at elevated temperatures. The addition of PP fibres to high-strength concrete (HSC) proved to have a positive effect; their presence had a greater impact on the compressive strength than on splitting the tensile strength (at temperatures above $200{ }^{\circ} \mathrm{C}$ ). A significant improvement in the residual mechanical properties of HSC was achieved by $2 \mathrm{~kg} \mathrm{~m}^{-3}$ of PP fibres in the mixture. Concrete specimens also lose mass at high temperatures. At up to $800{ }^{\circ} \mathrm{C}$, the mass loss is relatively smooth (after physically bound water 
has evaporated). However, beyond this temperature mass begins to decrease very rapidly and has been found to decline by as much as $45 \%$; the mass losses were not significantly influenced by the $w / c$ ratio nor by the type of aggregate. ${ }^{4}$

The currently valid standard governing the assessment of existing structures, ISO 13822:2010, ${ }^{7}$ states that an assessment of the real state of a building must be conducted with the real properties of the materials from which the building is made, not the material parameters described in the building's original design, or in any standard or directive. The assessment of the real properties of these materials must take into account their degradation and the possible loads and attacks they may be subjected to during the structure's service life. It is also necessary to consider atypical forms of damage, such as that caused by fire. However, there are no instructions for the efficient determination of the material properties necessary for performing explorations of the structural conditions of buildings damaged by fire.

This pilot study and literature review was performed as part of the authors' preparations for subsequent extensive research focused on the design of effective diagnostic methods for determining the current state of concrete structures damaged by high temperatures during exposure to fire. This future research will involve a variety of tests (commonly used for the determination of the properties of steel-reinforced concrete) performed on concrete specimens that have been loaded by high temperatures. The tests will be carried out after the specimens have cooled down to ambient temperature. The suitability of each method will be determined from the degree of change occurring in these properties after thermal loading compared with the properties of the reference material, which has not undergone thermal loading. The pilot study needed to be undertaken prior to performing this experimental research because of the need to optimise laboratory test procedures and test the behaviour of the concrete at elevated temperatures.

The paper focuses on the search for effective test methods for determining the influence of elevated temperatures on the physico-mechanical properties of concrete. Knowledge regarding this influence (possibly supplemented by mathematical modelling) is essential for assessing the state and behaviour of concrete structures after exposure to fire.

\section{THE EFFECT OF ELEVATED TEMEPARTURES ON CONCRETE}

Concrete is considered to be a fire-resistant material. This means that no combustion of the material will occur if it is exposed to fire. However, it must be understood that even though concrete is fire-resistant, it will degrade due to high temperatures and will undergo chemical changes which affect its physical and mechanical properties.

\subsection{Chemical and physical changes in concrete}

Concrete consists of a cement matrix and aggregate. These components react differently to elevated temperatures, and this causes changes at their interface. For this reason, the following paragraphs of the paper deal with an analysis of the effect of fire on each concrete component, and describe the behaviour of concrete as a whole (i.e., as a composite consisting of components with different properties).

\subsubsection{The effect of fire on hardened cement paste}

The fire gradually heats the cement paste and causes the evaporation of the water inside. Free water evaporates first, followed by the physically bound water, and after that, the water chemically bound in the hydration products. ${ }^{1,8}$ If the cement paste is heated under confined humid conditions, a hydrothermal reaction known as internal autoclaving can occur (simultaneous exposure to high pressure and high temperatures). ${ }^{1,9}$ It can activate changes in the microstructure of hydrates. The nature of the phase changes depends mainly on the mineral composition of the cement used, its $\mathrm{C} / \mathrm{S}$ ratio (the molar ratio of lime to silicon dioxide; $\mathrm{CaO} / \mathrm{SiO}_{2}$ ), the amount of fine particles the cement contains, the temperature and pressure, and on the duration of the thermal loading. ${ }^{1,8}$ The mechanical properties of the cement paste are strongly influenced by the chemical bonds and attractive forces between the layers of calcium hydro-silicate ( $\mathrm{CSH}$ compound). It is assumed that approximately $50 \%$ of cement paste's strength comes from the attraction between the $\mathrm{CSH}$ compounds due to their enormous specific surface area. ${ }^{1,8}$ Dehydration occurs between the CSH layers and causes a decrease in hydrate volume. This in turn increases the porosity of the cement matrix, resulting in increased overall pore volume and size. Deformations in the cement paste are caused by volume changes in these constituents; the hydrated phase shrinks and the non-hydrated phase expands. At temperatures around $200{ }^{\circ} \mathrm{C}$, the cement matrix expands slightly, while beyond this temperature, it shrinks rapidly. ${ }^{1,10}$ The heat first causes ettringite decomposition; in fact, this occurs even before the temperature reaches $100{ }^{\circ} \mathrm{C}$. CSH compound dehydration takes place gradually and starts when the heating has begun. The cement-paste structure is partly damaged by dehydration at temperatures as low as $105^{\circ} \mathrm{C}$, which is incidentally a temperature commonly used for drying building materials. ${ }^{1}$ The heating of hardened cement paste to $500-550{ }^{\circ} \mathrm{C}$ results in a rapid decrease in the content of portlandite $\left(\mathrm{Ca}(\mathrm{OH})_{2}\right)$, which decomposes into water vapour and $\mathrm{CaO} .{ }^{1,10}$ The reaction causes an increase in porosity and reduces the strength of the cement paste. However, research findings suggest the hydration process can be modified by the use of pozzolanic materials in concrete. Their hydration products are calcium hydro-silicate gels, which are resistant to higher temperatures. Their residues can be found in concrete 
elements exposed to temperatures of $600-700{ }^{\circ} \mathrm{C}$. For this reason, it is more suitable to use blended pozzolanic cements with a lower pozzolanic additive content and a higher content of fly ash- or slag-based materials. ${ }^{1,11}$ Nevertheless, when the fire is being extinguished, a large amount of water is sprayed onto the concrete. This can trigger expansive reactions (lime slaking), Equation (1):

$$
\mathrm{CaO}+\mathrm{H}_{2} \mathrm{O} \rightarrow \mathrm{Ca}(\mathrm{OH})_{2}
$$

and thus cause an increase in volume and damage the concrete further. ${ }^{12}$

\subsubsection{The effect of fire on aggregate}

Aggregate, like most solids, expands with rising temperature. The thermal expansion of aggregate is thus an important factor in the behaviour of concrete during a fire. A typical feature of thermally stable aggregate is its chemical and physical stability at high temperatures. Aggregate suitable for mixing into concrete that is intended to be resistant to high temperatures needs to have a low thermal expansion coefficient as well as negligible residual stress. For an aggregate to be considered thermally stable it must not change its mechanical properties (especially its compressive strength) or its volume at high temperatures. Such an aggregate must not lose mass until certain temperatures are reached, and thermal reactions must not occur within it. The absence of peaks in the curves obtained from differential thermal analysis (DTA) is essential. ${ }^{1,8}$

The mineralogical composition of aggregate determines its thermal deformation as each material has its own specific thermal expansion coefficient. Carbonate aggregates (limestones and dolomites) are stable up to $600{ }^{\circ} \mathrm{C}$; higher temperatures then lead to decomposition into $\mathrm{CaO}$ (portlandite) and $\mathrm{CO}_{2}$, which takes place at around $700{ }^{\circ} \mathrm{C}$. Furthermore, $\mathrm{CaO}$ formed by decarbonation can later hydrate when the concrete cools, increasing its volume by $44 \% .^{1,8,12}$

At a temperature of $573{ }^{\circ} \mathrm{C}$, siliceous aggregate transforms from $\beta$ - to $\alpha$-quartz modification, bringing with it a significant increase in volume. ${ }^{13}$ Research shows that the most suitable natural aggregates appear to be basalt, diabase and andesite. Aggregate composed of several types of minerals can have a tendency to disintegrate as a result of the different thermal expansions of each component, which then causes inter-crystalline stress and cracking. This is the reason why fib Bulletin No. $38^{13}$ does not recommend the use of aggregates consisting of minerals with different thermal expansions. In order to limit the occurrence of inter-crystalline cracks, concretes which are at risk of being exposed to temperatures above $700{ }^{\circ} \mathrm{C}$ must contain artificial aggregate which guarantees similar properties throughout its volume. In order to achieve resistance to temperatures above $1000{ }^{\circ} \mathrm{C}$, crushed chamotte, corundum, silicon carbide, crushed bauxite or chromite can be used as aggregate. Most igneous rocks (e.g., granites and diorites) can melt at such high temperatures. ${ }^{1,11}$

\subsubsection{Interaction between aggregate and cement paste}

If concrete is heated, the volume of the aggregate increases while the hardened cement paste surrounding the aggregate shrinks. As is well known, the "interfacial transition zone" (ITZ) between the cement matrix and the aggregate is the weakest part within the material's structure, even when the concrete is not being subjected to thermal loading. This is because of the increased stresses that occur between the aggregate and the cement matrix. These stresses can be increased by the abovementioned counteracting volume changes caused by high temperatures. ${ }^{1}$ Due to these counteracting volume changes, even greater tensile stresses occur within the ITZ and the concrete then suffers damage due to cracking. ${ }^{1}$

\section{EXPERIMENTAL PART}

\subsection{Materials and specimens}

A total of 21 prism specimens of $(100 \times 100 \times 400)$ $\mathrm{mm}$ in size were made for the purpose of studying non-destructive methods of testing concrete damaged by fire. The mixture consisted of Portland cement, sand (0-4 mm), aggregate $(8-16 \mathrm{~mm})$, superplasticizer and water. The use of mixture with gap-graded aggregate (the 4-8 $\mathrm{mm}$ fraction is absent) should improve the physico-mechanical properties of structural elements by reducing shrinkage and creep while increasing the strength and elasticity for the same cement content. It is also a suitable way of reducing costs. ${ }^{14}$ The composition of the fresh concrete mixture can be found in Table $\mathbf{1}$. The $w / c$ ratio was set at 0.46 (dimensionless).

Table 1: Composition of fresh concrete

\begin{tabular}{|c|c|}
\hline Component & $\begin{array}{c}\text { Dosage }\left(\mathrm{kg} \text { per } 1 \mathrm{~m}^{3}\right) \\
\text { of fresh concrete }\end{array}$ \\
\hline CEM I 42.5 R (Mokrá) & 345 \\
\hline Quartz sand (Žabčice) 0-4 mm & 848 \\
\hline $\begin{array}{c}\text { Gravel aggregate (Olbramovice) } \\
\text { 8-16 mm }\end{array}$ & 980 \\
\hline Sika ViscoCrete 2030 superplasticizer & 2.8 \\
\hline Water & 160 \\
\hline
\end{tabular}

The prisms were cast and, after demoulding, cured for $28 \mathrm{~d}$ under water. After drying under laboratory conditions, the specimens were additionally dried in a ceramic furnace at a temperature of $110{ }^{\circ} \mathrm{C}$ for $48 \mathrm{~h}$.

The dry specimens were then placed into a Rohde KE 130B electric-powered laboratory furnace with an $8-\mathrm{kW}$ output, and were subjected to loading by the following set of temperatures: $(200,400,600,800,1000$ and 1200$){ }^{\circ} \mathrm{C}$. The heating rate was $5{ }^{\circ} \mathrm{C} / \mathrm{min}$ and the nominal maximum temperature was maintained for $60 \mathrm{~min}$. Once their exposure to elevated temperatures was complete, the concrete specimens were allowed to gradually cool down in the ambient air. The concrete specimens underwent thermal loading at the age of $120 \mathrm{~d}$, which is 
in accordance with RILEM's recommendation that the specimen age be at least $90 \mathrm{~d} .{ }^{15}$ The mechanical properties of the concrete were then determined $60 \mathrm{~d}$ after the thermal loading took place. The reference specimens without thermal loading (kept at $20^{\circ} \mathrm{C}$ ) were also tested.

Each of the seven sets of specimens produced with the aim of determining the influence of temperature on concrete properties with the aid of non-destructive methods consisted of two prisms with the nominal dimensions $(100 \times 100 \times 400) \mathrm{mm}$ and two cubes with an edge length of $100 \mathrm{~mm}$. These cubes were cut from fragments from larger prism specimens with a central edge notch that had previously been subjected to three-point bending, which was another task of the executed project. In total, the residual properties of concrete after exposure to elevated temperatures were tested on 14 prisms and 14 cubes.

\subsection{Schmidt rebound hammer test}

The rebound hammer method is used for measuring the hardness of a material, i.e., the ability of the material to resist penetration. The rebound hammer test was performed using a Silver Schmidt ST/PC Type L hammer due to its low impact energy $(0.735 \mathrm{~N} \mathrm{~m})$, because the response of concrete after exposure to fire is expected to be brittle. The manufacturer of this device gives a possible compressive strength range for concrete of $10-100 \mathrm{MPa} .{ }^{16}$ It is possible to use this hammer to determine the parameters of specimens with a thickness of less than $100 \mathrm{~mm}$. The hardness was measured by taking a minimum of 9 valid readings from the surface of each test specimen. The distance between the measurement positions was at least $25 \mathrm{~mm}$, and all the positions were at least $25 \mathrm{~mm}$ from the edges of the specimen. ${ }^{16,17}$

The experiment was carried out on seven sets of specimens, each of which consisted of two prisms and two cubes. The specimens were placed into a universal testing machine press and stressed by a compressive load equal to $10 \%$ of their compressive strength. The prisms was clamped at both ends and their hardness tested by impacts of the plunger on the two opposing faces with the larger surface area of the prisms (in the direction of compaction) - each face was impacted 12 times. Valid measurements were evaluated according to standard EN 12504-2. ${ }^{17}$ The evaluation of the rebound value always had at least 10 valid readings available for each measured face. Hardness values were determined for every tested face; these were then averaged to represent the specimen as a whole.

The cubes were tested in a similar manner, with the exception of the amount of faces tested; a total of three faces of each specimen were impacted - the cross section, the face opposite the cross-section and the bottom face (in the direction of compaction). The evaluation of the hardness of the cube specimens was in accordance with the method described for the prisms. The rebound value for one temperature was then calculated as an average of the mean rebound value of a prism and the mean rebound value of a cube for that temperature.

Concrete hardness expressed as a rebound value is commonly used for estimating concrete strength. For the SilverSchmidt Type L hammer, the relevant standard ${ }^{17}$ recommends that the strength should be estimated using the formula given by the manufacturer, i.e., Proceq. For the given range of concrete strengths and rebound values $R$, the dependence of compressive strength $f_{\mathrm{c}, \mathrm{R}}$ on the rebound value is expressed as Equation (2): 16

$$
f_{\mathrm{c}, \mathrm{R}}=1.9368 \cdot \exp (0.0637 \cdot R)
$$

\subsection{Ultrasonic pulse velocity method}

An ultrasonic wave travelling through a material causes its particles to vibrate in different directions. The velocity of the ultrasonic wave depends on the material properties (especially the modulus of elasticity) of the specimen being tested. The velocity of ultrasonic waves in materials is often determined by means of the ultrasonic pulse velocity method. The principle of the method consists of sending ultrasonic pulses into a material and recording them once they have passed through. The time the pulse front needs to pass from the transmitter to the receiver is then used for calculating the ultrasonic pulse velocity. The modulus of elasticity is then determined from the pulse velocity and the material's bulk density. ${ }^{18}$

The experiment was carried out on the same seven sets of specimens as in the case of the Schmidt rebound hammer test. The transit times of the ultrasonic longitudinal waves pulse were measured using a Proceq Pundit Plus with two 54-kHz transducers. ${ }^{19}$ A sufficient acoustic coupling between the ultrasonic transducers and the specimen was achieved by applying plastic modelling clay. Each measurement started with the calibration of the testing instrument using a calibration rod. ${ }^{18,20}$

In order to determine the dependence of the modulus of elasticity on the temperature to which the concrete is exposed, it was first necessary to determine the bulk density of the specimens loaded by high temperatures. The bulk density was determined from the mass and dimensions (volume) of each specimen using the method presented in EN 12390-7. ${ }^{21}$

\subsection{Impact-echo method}

The impact-echo method is based on the principle of analysing the reflection of an impulse-induced mechanical wave. The wave generated by the impact of a mechanical hammer on the specimen surface passes through the structure of the material and reflects from the defects inside the specimen or on its surface, returning as vibration. ${ }^{22} \mathrm{~A}$ receiver on the surface detects the vibration in the time domain, which is then converted into the resonance frequency using the fast Fourier transform. ${ }^{22,23}$ The experiment was carried out on seven sets of cube specimens as in the case of the Schmidt rebound hammer test. 

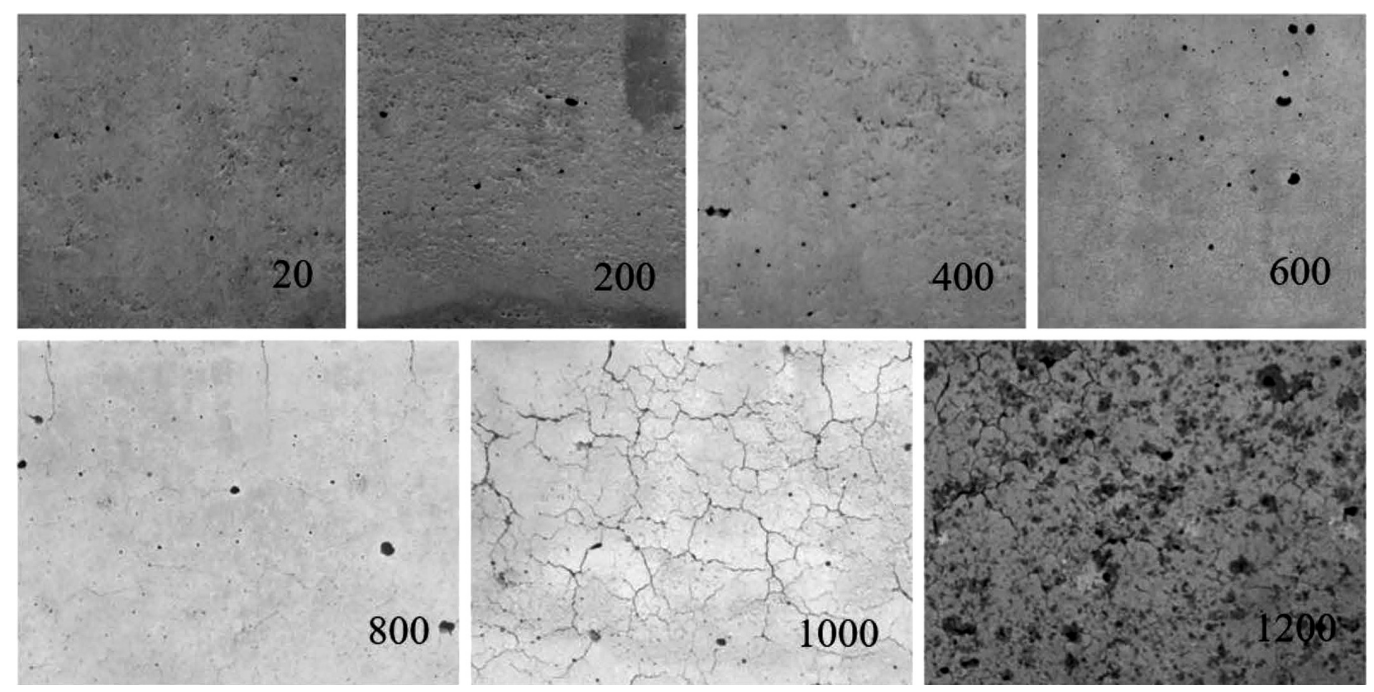

Figure 1: Colour changes of heated concrete (maximal temperatures $20-1200{ }^{\circ} \mathrm{C}$ )

\subsection{Compressive cube strength tests}

In the final stage of the experiment, compression tests were performed in accordance with the corresponding standards governing laboratory compressive strength testing. The cubes, which had first been tested by non-destructive methods, were subjected to a compression test according to EN $12390-3^{25}$ in order to determine a trend in strength changes as a result of exposure to elevated temperatures.

\section{RESULTS AND DISCUSSION}

After exposure to high temperatures, the specimens changed their appearance. Discolorations and cracks were visible on the surface at high temperatures. The appearance of the specimens after thermal loading is documented in Figure 1, where colour changes and the formation of cracks are visible.

The normal colour of reference unheated concrete was dark grey. After heating up to $200{ }^{\circ} \mathrm{C}$, no colour changes were observed. At temperatures of $400{ }^{\circ} \mathrm{C}$ and $600{ }^{\circ} \mathrm{C}$, the surface of the concrete became slightly pink. After heating up to $800{ }^{\circ} \mathrm{C}$, the concrete became light grey. After heating to $1000{ }^{\circ} \mathrm{C}$, the grey was very light, almost white-grey. A significant change occurred after the concrete was heated to $1200{ }^{\circ} \mathrm{C}$, when the concrete became brown. These changes in colour are the result of dehydration of the cement matrix and transformations of the aggregate minerals. ${ }^{1}$

There were no cracks on the surface of the specimens heated up to $400{ }^{\circ} \mathrm{C}$. Thermal loading up to $600{ }^{\circ} \mathrm{C}$ caused the appearance of small micro-cracks. After the concrete was loaded up to $800{ }^{\circ} \mathrm{C}$, the first cracks appeared, but they still did not cover the whole surface of the test specimen. The most apparent cracks could be observed on the specimens loaded up to $1000{ }^{\circ} \mathrm{C}$, where the cracks covered the whole surface, and their width increased up to $1 \mathrm{~mm}$. Near the edges of these specimens there were small local spalls in the concrete surface that revealed the presence of red-pink aggregate. The surfaces of specimens loaded up to $1200{ }^{\circ} \mathrm{C}$ were also covered with cracks, though there were fewer than the amount at $1000{ }^{\circ} \mathrm{C}$. In the case of the specimens heated to $1200{ }^{\circ} \mathrm{C}$, it was even possible to observe a degree of deformation - the specimens were bent into arches, with a deflection of approximately $3 \mathrm{~mm}$. The cracks created in the specimens were caused by volume changes occurring during their heating due to dehydration of the cement matrix and transformations of the aggregate minerals. ${ }^{1}$

\subsection{Compressive strength tests}

Figure 2 shows there was a relatively uniform decrease in the compressive strength of the concrete. The compressive strength determined for the reference unloaded concrete specimens was approx. $70 \mathrm{MPa}$. Exposure to a temperature of $200{ }^{\circ} \mathrm{C}$ caused this strength to drop by $5.7 \%$ (down to $65.9 \mathrm{MPa}$ ), while a temperature

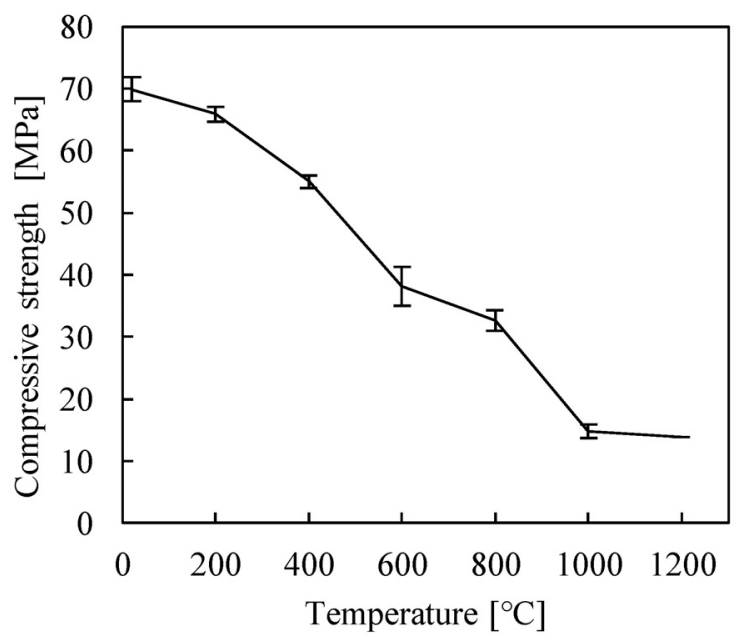

Figure 2: Development of compressive strength in relation to temperature 
of $400{ }^{\circ} \mathrm{C}$ resulted in a $21.2 \%$ decrease (to $55.0 \mathrm{MPa}$ ), $600{ }^{\circ} \mathrm{C}$ decreased it by $45.3 \%$ (to $38.2 \mathrm{MPa}$ ), $800{ }^{\circ} \mathrm{C}$ caused a $53.2 \%$ drop (to $32.7 \mathrm{MPa}$ ), $1000{ }^{\circ} \mathrm{C}$ resulted in a $78.8 \%$ decrease (to $14.8 \mathrm{MPa}$ ), and the strength of the concrete damaged by the highest temperature of $1200{ }^{\circ} \mathrm{C}$ decreased by $80.2 \%$ (to $13.8 \mathrm{MPa}$ ). The decreasing strength of the tested concrete cubes can be described by the following Equation (3):

$$
f_{\mathrm{c}}=-0.0529 \cdot T+73.345
$$

where $f_{\mathrm{c}}$ is the compressive strength of the concrete (MPa) and $T$ is the maximum nominal thermal load $\left({ }^{\circ} \mathrm{C}\right)$. The strength shows a strong negative dependence on the increasing temperature.

The decrease in the compressive strength is caused by the high thermal loading, which results in chemical and physical changes and subsequent gradual disintegration of the material's internal structure. Section 2 discusses this issue in more detail. One of the main causes of the decrease in strength can be attributed to the cracks that form and propagate as a consequence of these changes.

\subsection{Schmidt rebound hammer tests}

Figure 3 shows the rebound values of the thermally loaded concretes. The rebound value of the reference concrete was $55.9 \mathrm{Q}$. As the temperature increased, the rebound values changed. The temperature of $200{ }^{\circ} \mathrm{C}$ caused a very slight decrease in the rebound value; it was reduced by $1.2 \%$ to $55.2 \mathrm{Q}$. The temperature of $400{ }^{\circ} \mathrm{C}$ reduced it by $8.7 \%$ to $51.1 \mathrm{Q}$, while $600{ }^{\circ} \mathrm{C}$ caused it to decrease by $19.1 \%$ to $45.2 \mathrm{Q}, 800{ }^{\circ} \mathrm{C}$ reduced it by $43 \%$ to $31.9 \mathrm{Q}, 1000{ }^{\circ} \mathrm{C}$ caused a $53.5 \%$ decrease to $26.0 \mathrm{Q}$, and heating up to $1200{ }^{\circ} \mathrm{C}$ reduced the rebound value by $23.9 \%$ of the original, so down to $42.5 \mathrm{Q}$. This trend is visible in Figure 3, which shows the results of the rebound value measurements. The temperature of $200{ }^{\circ} \mathrm{C}$ causes no significant changes in the rebound value,

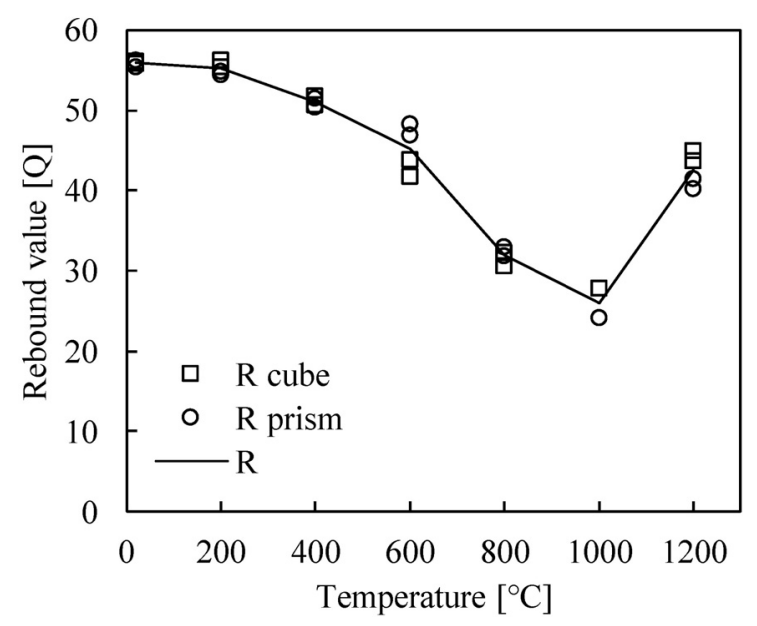

Figure 3: Rebound values measured from cubic and prismatic specimens in relation to temperatures and average rebound values for concrete heated up to selected temperatures which means that the hardness of the concrete is not reduced. Further increases in temperature slowly reduce the rebound value up to a temperature of $1000{ }^{\circ} \mathrm{C}$. The slow decrease in concrete hardness is caused by gradual transformations in the internal structure and the appearance of micro-cracks and cracks. On the other hand, thermal loading of the concrete above $1000{ }^{\circ} \mathrm{C}$ and up to $1200{ }^{\circ} \mathrm{C}$ results in a relatively sharp increase in the rebound values, and thus in hardness as well. The values approach the values measured for concrete heated to $600{ }^{\circ} \mathrm{C}$. The increase in hardness is caused by changes in the material structure - new crystalline phases are formed. The high temperatures cause the transformation of an important component of concrete - calcite (calcium carbonate $\mathrm{CaCO}_{3}$ ) - into a mineral known as wollastonite $\left(\mathrm{CaSiO}_{3}\right)$. According to the Mohs scale of mineral hardness, calcite has a hardness of 3, whereas the newly formed wollastonite is far harder, with a hardness of $5.26,27$

The compressive strength values calculated from the rebound values are displayed in Figure 4, which shows the trends of compressive strength development in relation to maximum nominal temperature - the black line shows the development of compressive strength measured by the compression test, while the grey line shows changes in compressive strength calculated from the rebound values obtained by the rebound hammer test. Only the compression test can be considered conclusive in this case. The rebound hammer test proved unsuitable for temperatures higher than $600{ }^{\circ} \mathrm{C}$ here. The values at $800{ }^{\circ} \mathrm{C}$ are too low, while on the other hand, at temperatures above $1000{ }^{\circ} \mathrm{C}$, the test returns values which are much higher compared to those obtained by destructive tests (due to the formation of new minerals and structures). At temperatures above $600{ }^{\circ} \mathrm{C}$, the use of the rebound hammer test cannot be recommended for estimating the compressive strength of concrete since its

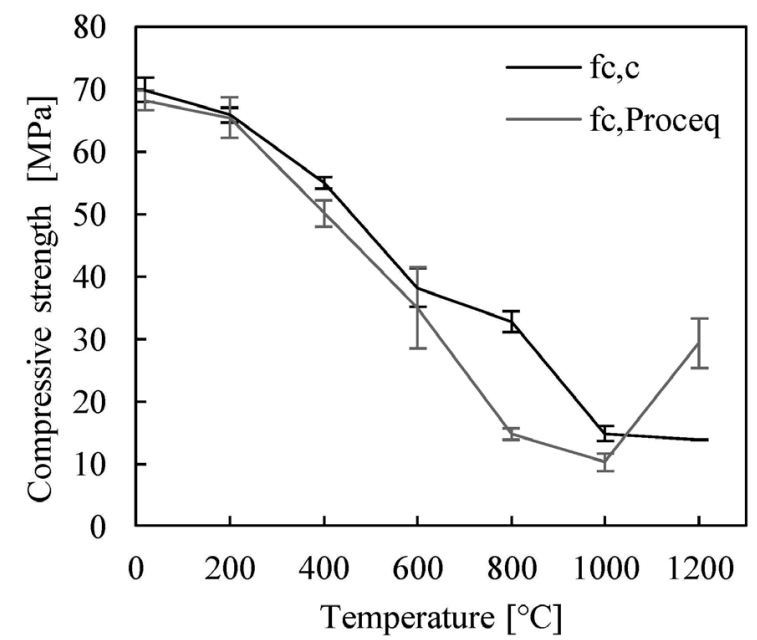

Figure 4: Comparison of the concrete compressive strengths calculated from the rebound values (according to the formula by Proceq) with the strengths determined by the compression test - average strength values are plotted in relation to thermal load 
behaviour is significantly different in terms of physical quantities and hardness. Hardness is generally considered a good indicator of concrete strength. However, these test results indicate the necessity to limit the scope of this assumption - after taking a broader spectrum of specimens into account. ${ }^{17}$

The usability of this method can be considerably limited in common practice due to the necessity of performing the tests on a flat surface. Such surfaces may not always be available due to the danger of explosive spalling (i.e., the breakdown of the surface layer), which can occur during fires even at relatively low temperatures due to the thermal expansion of water.

\subsection{The ultrasonic pulse velocity method}

The first step was to determine the bulk density of the thermally loaded specimens. ${ }^{21}$ Figure 5 shows the gradual decrease in bulk density across the temperature scale; this decrease is caused by the disappearance of water. First, free and physically bound water was removed in a dryer. This is why there are no significant decreases in bulk density at lower temperatures in the ceramic furnace. Compared with the value obtained for the reference concrete of $2340 \mathrm{~kg} \mathrm{~m}^{-3}$, there is only a $2.6 \%$ reduction to $2280 \mathrm{~kg} \cdot \mathrm{m}^{-3}$ at temperatures below $600{ }^{\circ} \mathrm{C}$. Above this temperature, chemically bound water is removed as well, especially via the dehydration of cement hydration products. This is why both bulk density and mass decrease: at a temperature of $1200{ }^{\circ} \mathrm{C}$ the bulk density reached $2040 \mathrm{~kg} \mathrm{~m}^{-3}$, which meant a reduction of $12.8 \%$ compared with the reference bulk density.

The main parameter observed by the method was the ultrasonic pulse velocity. The results are shown in Figure 6. The ultrasonic pulse front travelled through the reference concrete at an average velocity of $4420 \mathrm{~m} \mathrm{~s}^{-1} .^{17}$ As the thermal loading was increased up to $200{ }^{\circ} \mathrm{C}$, the

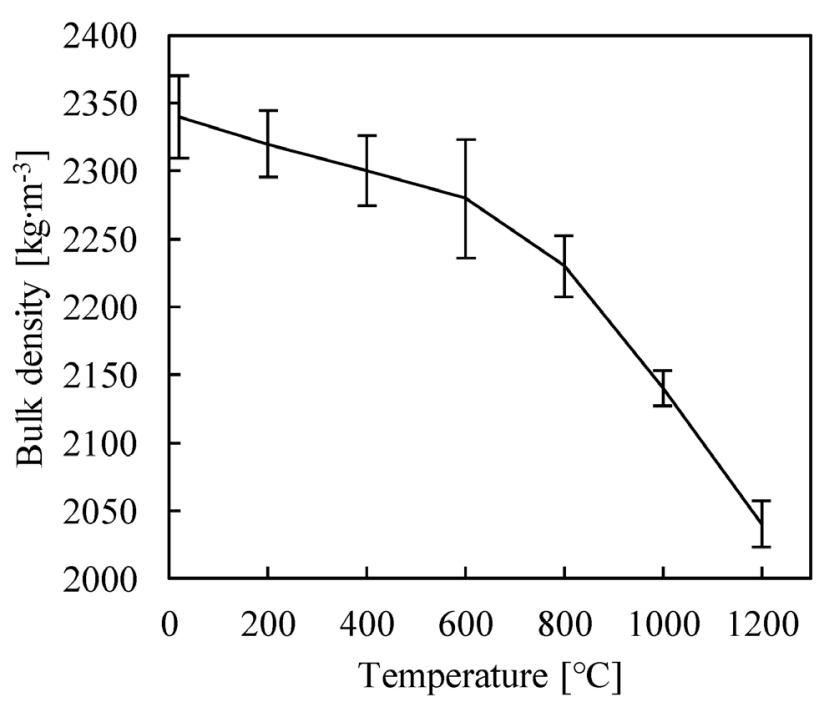

Figure 5: Decrease in bulk density in relation to increasing thermal load average velocity decreased by $5.7 \%$ to $4280 \mathrm{~m} \mathrm{~s}^{-1}$, while during loading up to $400{ }^{\circ} \mathrm{C}$, the value decreased by $25.8 \%$ to $3280 \mathrm{~m} \mathrm{~s}^{-1}$. At a temperature of $600{ }^{\circ} \mathrm{C}$, it decreased by $48.2 \%$ to $2290 \mathrm{~m} \mathrm{~s}^{-1}$, at $800{ }^{\circ} \mathrm{C}$, it decreased by $67.2 \%$ to $1450 \mathrm{~m} \mathrm{~s}^{-1}$, at $1000{ }^{\circ} \mathrm{C}$, it dropped by $76.0 \%$ to $1060 \mathrm{~m} \mathrm{~s}^{-1}$, and at $1200{ }^{\circ} \mathrm{C}$, it decreased by $51.4 \%$ from the reference value to $2150 \mathrm{~m} \mathrm{~s}^{-1}$. Figure 6 shows a constant decrease in ultrasonic pulse velocity until the temperature reached $1000{ }^{\circ} \mathrm{C}$. At higher temperatures, the structural changes cause the ultrasonic wave velocity to increase again.

The overall structure of the concrete changes when its temperature exceeds $1000{ }^{\circ} \mathrm{C}$. Due to the melting of cement paste, the conversion of hydraulic bonds into ceramic ones is initiated. For a new material with ceramic bonds, it is expected to increase the material's elasticity. The increase in ultrasonic wave velocity is attributed to this phenomenon. ${ }^{28,29}$

Figure 6 clearly shows the different development of ultrasonic pulse velocity in relation to specimen shape a cube with an edge length of $100 \mathrm{~mm}$ and a prism with a width of $100 \mathrm{~mm}$ and a length of $400 \mathrm{~mm}$. The standard describing the ultrasonic pulse velocity method ${ }^{18}$ states that the short pulse velocity created by vibration is independent of the size and shape of specimens as long as the side dimensions are above the acceptable limit. The standard ${ }^{18}$ lists the minimum dimensions with regard to the pulse velocity in concrete for a $54-\mathrm{kHz}$ transducer (used in this experiment), Table 2. Despite the fact that the side dimensions of all specimens were greater than those stated by the standard, the specimen shape still had an effect on short pulse velocity. No explanation of this inconsistency has been found in the currently available literature, which is why it would be beneficial to investigate the issue of the real influence of specimen shape and size on ultrasonic pulse velocity.

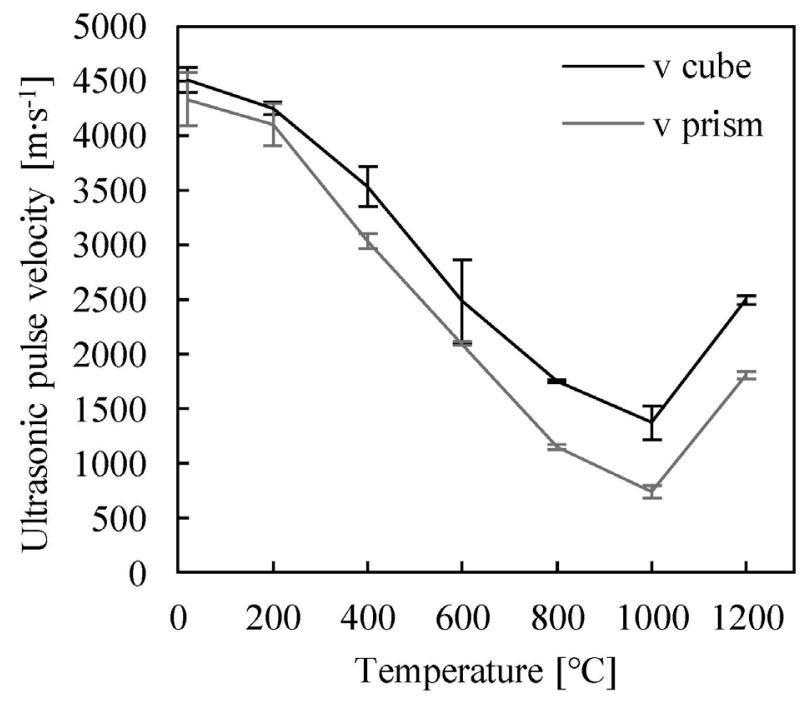

Figure 6: Changes in ultrasonic pulse velocity in relation to thermal loading; specimen shape taken into account 
Table 2: Influence of specimen size on ultrasonic pulse velocity ${ }^{18}$

\begin{tabular}{|c|c|c|c|}
\hline \multirow{2}{*}{$\begin{array}{c}\text { Transducer } \\
\text { frequency } \\
(\mathrm{kHz})\end{array}$} & \multicolumn{3}{|c|}{ Ultrasonic pulse velocity in concrete $\left(\mathrm{km} \mathrm{s}^{-1}\right)$} \\
\cline { 2 - 4 } & 3.50 & 4.00 & 4.50 \\
\hline 54 & Smallest acceptable side dimensions $(\mathrm{mm})$ \\
\hline 5 & 65 & 74 & 83 \\
\hline
\end{tabular}

Subsequently, the obtained ultrasonic pulse velocity values were used in the determination of the concrete's modulus of elasticity. Figure 7 shows the dependence of the dynamic modulus of elasticity on the maximum nominal temperature to which the concrete was exposed. Almost the entire temperature spectrum shows a considerable decrease in the modulus of elasticity. Only at a temperature of $1000{ }^{\circ} \mathrm{C}$ is there a slight increase. The reduction in the material's modulus of elasticity is caused by the overall degradation of the concrete due to cracking. The slight increase at temperatures above $1000{ }^{\circ} \mathrm{C}$ is caused by sintering of the material and by the formation of a new structure with wollastonite.

\subsection{The impact-echo method}

The dynamic modulus of elasticity was also determined by means of the impact-echo method. The test results are plotted in Figure 7, which shows that the losses in modulus of elasticity correspond to the results determined by means of the ultrasonic pulse velocity method.

\subsection{Plans for the future experiments}

Subsequent experimental investigations will aim to design effective methods for the assessment of the condition of concrete in concrete structures damaged by fire. In addition to the standard mechanical parameters, basic fracture properties will also be determined. Both destructive and non-destructive tests are expected to be performed on statistically significant sets of concrete specimens.

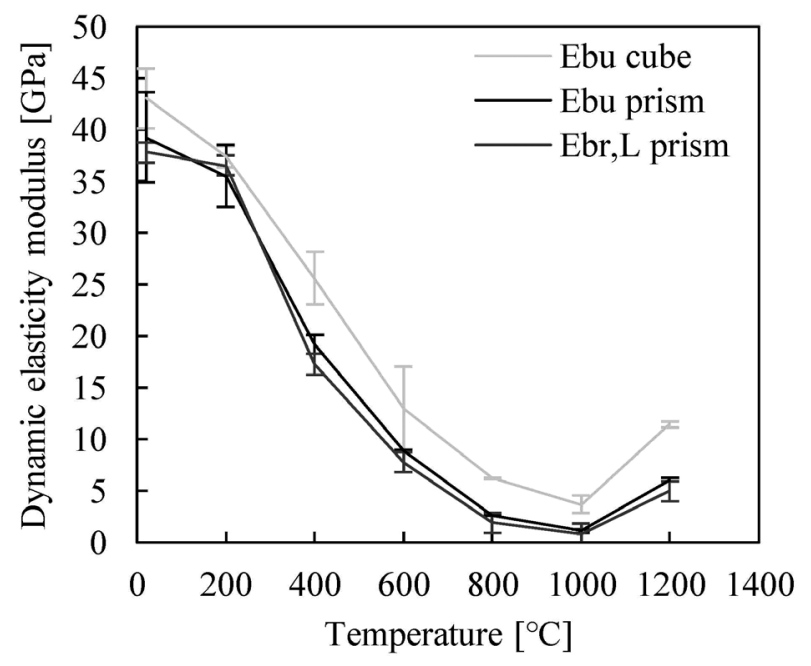

Figure 7: Dependence of the dynamic moduli of elasticity $E_{\mathrm{bu}}, E_{\mathrm{br}}$ on thermal loading
Future research will also focus on obtaining suitable data to aid in the design of methodology for determining the residual concrete properties in steel-reinforced concrete structures. Thus, instead of the common system of manufacturing and testing small concrete specimens (e.g. cubes with an edge length of $150 \mathrm{~mm}$ or prisms of the nominal dimensions $(100 \times 100 \times 400) \mathrm{mm}$, the tests will be performed on large steel-reinforced slabs. This should better simulate the material's behaviour in a real structure.

Seven steel-reinforced concrete panels with dimensions of $(2300 \times 1300 \times 150) \mathrm{mm}$ will be prepared. The fresh concrete formula will be designed to correspond to a concrete with ordinary fire resistance; it will be a C30/37 strength class concrete, exposure class XC3, containing limestone aggregate. The concrete panels will be made with reinforcement at the bottom face. Type-K thermocouples will be embedded in the panels in order to measure the temperature during testing. The panels will be identified according to the target thermal load as T020, T200, T400, T600, T800, T1000, and T1200. For $7 \mathrm{~d}$ after casting, the slabs will be wrapped in a plastic film that prevents them from drying, and stored in an environment with a temperature of $20 \pm 2{ }^{\circ} \mathrm{C}$. Afterwards, they will be demoulded and stored in the ambient air for $84 \mathrm{~d}$, since according to the Recommendations of RILEM TC 200-HTC, ${ }^{15}$ the age of the tested concrete should be more than $90 \mathrm{~d}$.

A total of 6 fire tests will be performed. The test panels will be removed from the environment in which they aged, and will be placed onto the top of a gas-burning fire resistance test furnace used for the study of material behaviour at elevated temperatures. This furnace is operated by the AdMaS Research Centre at Brno University of Technology. The construction of the furnace allows the heating of one (bottom) side of the panel. The top face will be left to cool spontaneously in the surrounding environment.

The thermal loading of the panels will follow the standard temperature curve stating gas temperatures $\theta_{g}$ in Equation (4):

$$
\theta_{\mathrm{g}}=20+345 \cdot \log _{10}(8 t+1)
$$

where $t$ represents the time since the start of the fire in minutes. The equation of the curve written in EN 1991-1-230 represents a common type of fire which may affect a building in rare cases. Each specimen will be heated up to its target temperature with regard to the defined temperature curve $(200,400,600,800,1000$, 1200) ${ }^{\circ} \mathrm{C}$. The given thermal load will then be maintained for 60 more minutes so that the heat may spread uniformly throughout the whole panel. Once the panel has been exposed to the elevated temperatures, it will be left on top of the furnace until it cools down to the ambient temperature. 


\subsubsection{Non-destructive testing of the panels}

The Silver Schmidt L rebound hammer will be used to determine the rebound number according to $\mathrm{EN}$ $12504-2^{17}$. This number will then be recalculated to the compressive strength using the calibration relationship provided by the manufacturer as well as the standard.

Using the ultrasonic pulse velocity test in accordance with EN $12504-4,{ }^{18}$ the transit time of the ultrasonic pulse through the specimen will be measured at the same positions on the surface of the panels. This value is required for the calculation of the velocity of the ultrasonic pulse. The dynamic modulus of elasticity will be calculated from the ultrasonic pulse velocity, and the bulk density determined according to EN 12390-7.21

\subsubsection{Destructive tests}

Each panel will be cut into a set of specimens, which will then be tested in accordance with the corresponding standards:

- 6 core specimens of $50 \mathrm{~mm}$ in diameter and cut to a length of $100 \mathrm{~mm}$ - for the determination of cylinder compressive strength (EN 12390-3), ${ }^{25}$

- 6 core specimens of $100 \mathrm{~mm}$ in diameter and cut to a length of $100 \mathrm{~mm}$ - for the determination of splitting tensile strength (EN 12390-3), ${ }^{25}$

- 6 prisms with dimensions of $(100 \times 100 \times 400) \mathrm{mm}-$ for the determination of flexural strength (EN 12390-5), ${ }^{31}$

- 6 prisms with dimensions of $(100 \times 100 \times 400) \mathrm{mm}$ and provided with an initial central notch - for three-point bending tests. The data from the fracture tests (load vs. displacement diagrams) will be applied in the evaluation of the modulus of elasticity values. ${ }^{32}$ In addition, the fracture energy ${ }^{33}$ and effective fracture toughness ${ }^{32}$ values will be determined. Apart from the determination of commonly used values, attention will be paid to the application of the Double- $K$ fracture model ${ }^{34}$ in order to identify the initiation component of the stress intensity factor (to be used in the calculation of the load at which stable crack propagation starts in an initial stress concentrator).

\subsubsection{Evaluation of the planned tests}

Percentage differences between the individual physico-mechanical properties of the concrete specimens and panels after high thermal loading and subsequent cooling will be determined, making use of different methods. The parameters determined for the unheated concrete (T20) will be used as a reference.

The methods will be arranged according to the percentage differences between the values measured for high temperature exposure and the results of tests performed on specimens not exposed to fire. In cases when a method provides significant changes in properties, it will be recommended for the testing of concrete structures exposed to elevated temperatures.
Calibration relationships will be determined between the destructive and non-destructive methods.

\section{CONCLUSIONS}

The pilot research described in this article has gathered the most important information about the behaviour of concrete during a fire, especially from the material perspective. The data from this research will be used during upcoming extensive research that will focus on searching for effective test methods for determining the influence of elevated temperatures on the physicomechanical and mechanical fracture properties of concrete. This knowledge (possibly supplemented by mathematical modelling) is essential for assessing the state and behaviour of concrete structures after exposure to fire.

The experiment results have revealed the following facts:

The necessity to investigate the real influence of specimen shape and size on ultrasonic pulse velocity.

- All the non-destructive tests performed on concrete exposed to elevated temperatures have proved the fact that many of its properties improve to different extents at temperatures above $1000{ }^{\circ} \mathrm{C}$. At these extremely high temperatures, minerals undergo transformations which cause the hardness of concrete as well as its dynamic modulus of elasticity to increase. However, compressive strength continues to degrade at these temperatures.

- Concrete hardness determined using the SilverSchmidt rebound hammer, as well as the modulus of elasticity determined via the ultrasonic pulse velocity or impact-echo method, correspond to the destructively determined compressive strength of concrete at temperatures of up to $600{ }^{\circ} \mathrm{C}$. However, at temperatures higher than that, the dependencies begin to deviate. For this reason, the non-destructive methods used here cannot be recommended for the determination of the compressive strength of concrete exposed to temperatures above $600{ }^{\circ} \mathrm{C}$.

- It will be necessary to find suitable, effective, and commonly applicable methods for the determination of the properties of concrete. One solution could be to use calibration relationships which more closely correspond to the real properties of a material subjected to such a high thermal load.

\section{Acknowledgment}

This outcome has been achieved with the support of the specific research programme at Brno University of Technology, project No. FAST-S-17-4304. The financial support of Czech Science Foundation project No. 16-18702S (AMIRI) is also gratefully acknowledged. 


\section{ROZSYPALOVÁ et al.: A PILOT STUDY OF METHODS FOR MEASURING THE RESIDUAL ...}

\section{REFERENCES}

${ }^{1}$ I. Hager, Behaviour of cement concrete at high temperature, Bull. Pol. Acad. Sci.-Te., 61 (2013), 145-154, doi:10.2478/bpasts-20130013

${ }^{2}$ EN 1992-1-2:2004 - Eurocode 2: Design of concrete structures, Part 1-2: General rules, Structural fire design, Brussels

${ }^{3}$ G. A. Khoury, Compressive strength of concrete at high temperatures: a reassessment, Mag. Concrete Res., 44 (1992), 291-309, doi:10.1680/macr.1992.44.161.291

${ }^{4} \mathrm{O}$. Arioz, Effects of elevated temperatures on properties of concrete, Fire Safety J., 42 (2007), 516-522, doi:10.1016/j.firesaf.2007.01.003

${ }^{5}$ H. Yang, Y. Lin, Ch. Hsiao, J.-Y. Liu, Evaluating Residual Compressive strength of concrete at elevated temperatures using ultrasonic pulse velocity, Fire Safety J., 44 (2009), 121-130, doi:10.1016/ j.firesaf.2008.05.003

${ }^{6}$ M.-X. Xiong, J.Y. Richard Liew, Mechanical behaviour of ultra-high strength concrete at elevated temperatures and fire resistance of ultra-high strength concrete filled steel tubes, Mater. Design, 104 (2016), 414-427, doi:10.1016/j.matdes.2016.05.050

${ }^{7}$ ISO 13822:2010 - Bases for design of structures, Assessment of existing structures, Brussels

${ }^{8}$ Q. Ma, R- Guo, Z. Zhao, Z. Lin, K. He, Mechanical properties of concrete at high temperature - A review, Constr. Build. Mater., 93 (2015), 371-383, doi:10.1016/j.conbuildmat.2015.05.131

${ }^{9}$ J. Piasta, Heat deformations of cement paste phases and the microstructure of cement paste, Mater. Struct., 17 (1984), 415-420, doi:10.1007/BF02473981

${ }^{10}$ E. Menéndez, L. Vega, C. Andrade, Use of decomposition of portlandite in concrete fire as indicator of temperature progression into the material: Application to fire-affected builds, J. Therm. Anal. Calorim, 110 (2012), 203-209, doi:10.1007/s10973-011-2159-4

${ }^{11}$ J. Válek, Research and development of composites materials with higher resistance to high temperatures, doctoral thesis, Brno University of Technology, Brno 2014, 188

${ }^{12}$ P. Rovnaník, A. Dufka, Effect of the aggregate type on the properties of alkali-activated slag subjected to high temperatures, Mater. Tehnol., 49 (2015), 709-713, doi:10.17222/mit.2014.116

${ }^{13}$ fib Bulletin No. 38, Fire design of concrete structures, Materials, structures and modelling, fédération internationale du béton, Stuttgart 2007, 106

${ }^{14} \mathrm{M}$. Collepardi, The new concrete, $2^{\text {nd }}$ ed., Grafiche Tintoretto, 2010, 436

${ }^{15}$ Recommendation of RILEM TC 200-HTC: Mechanical concrete properties at high temperatures - modelling and applications, Mater. Struct., 40 (2007) 9, 855-864, doi:10.1617/s11527-007-9286-1

${ }^{16}$ Proceq, Schmidt rebound hammers for concrete and rock testing. https://www.proceq.com/
${ }^{17}$ EN 12504-2:2012 - Testing concrete in structures, Part 2: Non-destructive testing, Determination of rebound number, Brussels

${ }^{18}$ EN 12504-4:2004 - Testing concrete, Part 4: Determination of ultrasonic pulse velocity, Brussels

${ }^{19}$ Proceq, Pundit ultrasonic pulse velocity and pulse echo tomography testing. https://www.proceq.com/

${ }^{20}$ U. Dilek, Ultrasonic Pulse Velocity in nondestructive evaluation of low quality and damaged concrete and masonry construction, J. Perform. Constr. Fac., 21 (2007), 337-344, doi:10.1061/(ASCE) 0887-3828(2007)21:5(337)

${ }^{21}$ EN 12390-7:2009 - Testing hardened concrete, Part 7: Density of hardened concrete, Brussels

${ }^{22}$ K. Krzemień, I. Hager, Post-fire assessment of mechanical properties of concrete with the use of the impact-echo method, Constr. Build. Mater., 96 (2015), 155-163, doi:10.1016/j.conbuildmat.2015.08.007

${ }^{23}$ F. Schubert, B. Köhler, Ten Lectures on Impact-Echo, J. Nondestruct. Eval., 27 (2008), 5-21, doi:10.1007/s10921-008-0036-2

${ }^{24}$ L. Topolár, P. Rypák, K. Timčáková-Šamárková, L. Pazdera, P. Rovnaník. Non-traditional non-destructive testing of the alkali-activated slag mortar during the hardening, Mater. Tehnol., 50 (2016), 7-10, doi: $10.17222 / \mathrm{mit} .2014 .130$

${ }^{25}$ EN 12390-3:2009 - Testing hardened concrete, Part 3: Compressive strength of test specimens, Brussels

${ }^{26}$ Webmineral, Wollastonite-1A Mineral Data. http://www.webmineral.com/data/Wollastonite-1A.shtml\#.WgwAO0qnE2w

${ }^{27}$ Webmineral, Calcite Mineral Data. http://webmineral.com/data/ Calcite.shtml\#.WgwAlUqnE2y

${ }^{28}$ Z. Bažant, M. F. Kaplan, Concrete at high temperatures: Material properties and mathematical models, $1^{\text {st }}$ ed., Longman Group Limited, Essex 1996, 412

${ }^{29}$ L. Pazdera, L. Topolar, K. Mikulasek, J. Smutny, H. Seelmann, Non-linear characteristics of temperature degraded concrete at high temperature, Procedia Eng, 190 (2017), 100-105, doi:10.1016/ j.proeng.2017.05.313

${ }^{30}$ EN 1991-1-2:2002 - Eurocode 1, Actions on structures, Part 1-2: General actions, Actions on structures exposed to fire, Brussels

${ }^{31}$ EN 12390-5:2009 - Testing hardened concrete, Part 5: Flexural strength of test specimens, Brussels

${ }^{32}$ B. L. Karihaloo, Fracture Mechanics and Structural Concrete, Longman Scientific \& Technical, 1995 New York, 346

${ }^{33}$ RILEM TC-50 FMC (Recommendation): Determination of the fracture energy of mortar and concrete by means of three-point bend test on notched beams, Materials \& Structures, 18 (1985), 285-290

${ }^{34}$ S. Kumar, S. V. Barai, Concrete Fracture Models and Applications, Springer, Berlin 2011, 406 